Jurnal Riset Kesehatan, 9 (1), 2020, 65 - 71

DOI: $10.31983 /$ jrk.v9i1.5736

Jurnal Riset Kesehatan

http://ejournal.poltekkes-smg.ac.id/ojs/index.php/jrk

\title{
HEALTH RISK ANALYSIS OF LEAD LEVELS (Pb) IN GREEN LEAFY VEGETABLES FROM TRADITIONAL MARKETS AND SUPERMARKET IN SEMARANG CITY: A PRELIMINARY STUDY
}

\author{
Puteri Inandin Nabiha $\left.{ }^{a *}\right)$; Ririn Arminsih Wulandari ${ }^{b}$ \\ a Postgraduate student of Public Health Sciences, Department of Environmental Health, Faculty of \\ Public Health, Universitas Indonesia, Depok, Indonesia \\ ${ }^{b}$ Department of Environmental Health, Faculty of Public Health, Universitas Indonesia, Depok, \\ Indonesia
}

\begin{abstract}
Contamination of vegetables (as an important part of people's food diet) with heavy metals is a health problem. Lead, one most common heavy metals, can pose significant health risks to humans, so metals must be controlled in food sources. Therefore, monitoring heavy metal levels in vegetables can provide useful information to ensures food safety. Samples of Green Spinach (Amaranthus gangeticus) $(\mathrm{n}=4)$ Kale or Water Spinach (Ipomoea aquatica) $(\mathrm{n}=4)$ and Green Mustards (Brassica rapa I. Subsp. Perviridis Bayley) $(\mathrm{n}=4)$ were collected from three traditional markets and one supermarket in Semarang City, Central Java. The purpose of this descriptive study was to assess $\mathrm{Pb}$ contamination on raw and boiled vegetables and the health risks for residents in Semarang. The $\mathrm{Pb}$ of the samples was measured using atomic absorption spectrophotometer (AAS). The result showed $\mathrm{Pb}$ in all samples exceeded the standard values from WHO/FAO $(0,3 \mathrm{mg} / \mathrm{kg})$, Indonesian National Standard (SNI) limit for Heavy Metals on Food $(0,5 \mathrm{mg} / \mathrm{kg})$ and The National Agency of Drug and Food Control of the Republic of Indonesia (BPOM) $(0,2 \mathrm{mg} / \mathrm{kg})$. The highest accumulation of $\mathrm{Pb}$ found in kale from ' $\mathrm{B}$ ' Traditional Market with 6,123 mg/kg and the lowest was kale from supermarket $0,25 \mathrm{mg} / \mathrm{kg}$. The boiling process for vegetables may increase the $\mathrm{Pb}$ concentration, considering the cookware materials. Results revealed that there is no risk of potential health problems for residents in the city with current $\mathrm{Pb}$ concentration.
\end{abstract}

Keywords: Lead; Pb; Vegetables; Health Risk; Market

\section{Introduction}

Noncommunicable diseases (NCDs), especially cardiovascular diseases (CVDs), cancer, obesity and type 2 diabetes mellitus, currently kill more people every year than any other cause of death. Four factors in the epidemiology of these diseases including poor diet, physical inactivity, tobacco, and alcohol use - are of overwhelming importance to public health (WHO, 2018) Fruit and vegetables are an important component of a healthy diet and, if consumed daily in sufficient amounts, could help prevent major diseases such as CVDs and certain cancers (WHO, 2003; Saha et al., 2019).

The 2014 Individual Food Consumption Survey (SKMI) showed that almost all

*) Correspondence Author (Puteri Inandin Nabiha) E-mail: puteri.inandin@ui.ac.id
Indonesians consumed vegetables daily ( $94.8 \%)$ with a mean consumption of vegetables of 70.0 grams/person /day. When compared to the recommended adequacy according to balanced nutrition guidelines, the consumption of these vegetables is fairly low (Hermina \& Prihatini, 2016). The results of the 2016 National Socio-Economic Survey (SUSENAS) mentioned that vegetables that are highly-consumed by many Indonesian are spinach, kale, and mustard greens.

Sustainable Development Goals (SDGs) goals number 2 aims to end hunger, achieve food security, and improved nutrition, and promote sustainable agriculture, also creating good food systems (UN, 2015). Food production and consumption must be oriented to the secured-safety manner and able to fulfill 
people's nutrition without having undesirable effects on the environment and especially to human health. Safe and healthy agricultural land, soil, air, and plant resources are the main sources in the food production lengthy process. Pesticide-free agricultural land or organic plants were limited due to increasing environmental pollution in various areas.

Environmental pollution occurs due to industrial processes that develop along with the social-economic growth. The industry produces metal waste that can pollute the environment which then enters water bodies, air, and soil. Pollution of the water bodies, air, and soil leads to all living things around the area to be exposed to heavy metals. Plants that need soil and water to grow can be contaminated with heavy metals from the industry or residue from the excessive use of chemical pesticides or fertilizers use at the time of the agricultural process. Charlena (2004) found phosphate-based fertilizer which is widely used by farmers in Indonesia contains lead from 5 to $156 \mathrm{ppm}$ (Charlena, 2004). Heavy metal elements such as lead $(\mathrm{Pb})$, chromium $(\mathrm{Cr})$, arsenic (As), mercury $(\mathrm{Hg})$ and cadmium $(\mathrm{Cd})$ that had accumulated in plants cannot be removed only by washing or cooking before consumption (Abdel-Rahman, Ahmed, \& Marrez, 2018; Sattar, Anjum, \& Sameen, 2015).

Humans can be exposed to heavy metals through the ingestion or inhalation route. There are several sources of heavy metals in food such as contaminated fruits, vegetables, and drinking water (Kachenko \& Singh, 2006). Vegetables absorb and accumulate heavy metals mainly through the root system of the soil, stomata of leaves, stem, and root of tubers (shallots) (Charlena, 2004; Li, Hua, \& Yue, 2004). Accumulation of heavy metals in vegetables causes health risks to the human body such as damage to the kidney, reproductive system disorders, and nerve damage (Granero \& Domingo, 2002; Wani, Ara, \& Usmani, 2015). Lead can affect the intelligence development of children, cause the excessive lead in the blood, and cause hypertension, nephropathy, and cardiovascular disease (ATSDR, 2019). Lead poisoning can be chronic and acute, depends on the duration of exposure and the dose of lead toxicity. Chronic lead poisoning is characterized by depression, headaches, reduced ability to remember and concentrate, and sleep disorders (Widaningrum, Miskiyah, \& Suismono, 2007).

Based on some of the results of previous studies, the levels of lead in vegetables in some areas have exceeded food quality safety limits.
Triani reported that the $\mathrm{Pb}$ content in kale in Bali Province ranged from 1.64 to $2.82 \mathrm{mg} / \mathrm{kg}$ (Triani, Gunam, \& Arnata, 2012). Research conducted by Erdayanti (2015) in Pekanbaru showed that the spinach and spinach commodities in the region contained the highest $\mathrm{Pb}$ metal in spinach $(0.4234$ $\mathrm{mg} / \mathrm{kg}$ ) (Erdayanti, Hanifah, \& Anita, 2015). Pb levels in kale in three traditional markets in Cilandak, South Jakarta reached up to 22.06 $\mathrm{mg} / \mathrm{kg}$ (Adila \& Laz, 2016) while the maximum limit of lead elements in fruits and vegetables according to the Indonesian National Standard (SNI) 7387 of 2009 concerning Maximum Limits Contamination of Heavy Metals in Food is 0.5 $\mathrm{mg} / \mathrm{kg}$.

The study that focuses on heavy metals in vegetables consumed every day by the community in Semarang and the health risks impact on the public as consumers are still very limited. Therefore, the purpose of this descriptive study is to find out the level of lead in spinach, kale, and mustard greens bought by the public on the market, before receiving any treatment, and to analyze the potential health risks for the consumer community. More specifically, kale as a vegetable with the highest lead level from this preliminary research was then continued being treated with washing to boiling, to assess the lead levels from the cooking process.

\section{Method}

\section{Sample Collection and Pre-Treatment}

Vegetable samples were obtained from 4 locations - 3 large traditional markets and a modern supermarket, located in Semarang City. The total sample size from 4 different locations was 12 vegetables. Laboratory examination using the Atomic Absorption Spectrophotometry (AAS) method was carried out to determine the lead levels quantitatively conducted at the Diponegoro University Environmental Engineering Laboratory, Semarang. Spinach, kale, and mustard greens are bought in traditional markets and supermarkets, then weigh every 40 grams for treatment. Sampling time is carried out during July 2019 at 06.00-09.00 am.

Additional treatment of the kale from 'B' traditional market which in the preliminary study had the highest lead level, was continued until the washing and boiling process. The kale then washed using aqua dest to ensure there is no residue of dirt or any lead contamination sourced other than from the vegetable samples. The kale sample also boiled with aqua dest. The vegetables are added after the water boiling and 
keep boil with all the vegetable parts that were immersed for 2 minutes. The pan for boiling was made from aluminum for the reference of material used by many in the Indonesian household. The sample then labeled and coded, stored in a sterile polyethylene bag, and immediately sent to the laboratory for the destruction process and AAS testing on the same day when the sample is obtained from the market.

\section{Chemical Process}

This process is carried out to wet the sample of the vegetables before AAS testing. Samples of each vegetable weighed 2-5 grams. $\mathrm{HCl}$ has added $9 \mathrm{ml}$ and $3 \mathrm{ml} 65 \% \mathrm{HNO}_{3}$. Furthermore, it is heated using a stove to boil for 30 minutes then filter using filter paper. Next, the vegetable solution is diluted by adding aqua dest to a volume of $50 \mathrm{ml}$. After that, the sample is examined using the AAS.

\section{Result and Discussion}

From the twelve vegetable samples that had tested, the results showed that the lead levels contained exceeded the recommended limits according to WHO / FAO, Indonesian National Standard (SNI) Number 7387: 2009 concerning Maximum Limits of Contamination of Heavy Metals in Food, and the Food and Drug Supervisory Agency (BPOM). The highest concentration of lead was found in kale vegetables originating from ' $\mathrm{B}$ ' traditional market $(6.123 \mathrm{mg} / \mathrm{kg}$ ) while the lowest was also kale but originating from the supermarket $(0,250 \mathrm{mg} / \mathrm{kg})$. Based on our investigations, vegetables from ' $\mathrm{A}$ ' traditional market were sourced from Mranggen Subdistrict, Demak Regency. While vegetables from ' $B$ ' and ' $C$ ' traditional markets and supermarket were originated from Bandungan District, Semarang Regency.

Table 1. Pb levels $(\mathrm{mg} / \mathrm{kg})$ in green vegetables in Traditional Markets and Supermarket in Semarang City without Treatment

\begin{tabular}{|c|c|c|c|c|c|c|}
\hline \multirow[b]{2}{*}{ Vegetables } & \multirow[b]{2}{*}{$\mathbf{n}$} & \multicolumn{4}{|c|}{ Sample Locations } & \multirow[b]{2}{*}{ Avg. } \\
\hline & & $\begin{array}{c}\text { A Market } \\
\mathrm{Pb}(\mathrm{mg} / \mathrm{kg})\end{array}$ & $\begin{array}{c}\text { B Market } \\
\mathrm{Pb}(\mathrm{mg} / \mathrm{kg})\end{array}$ & $\begin{array}{c}\text { C Market } \\
\mathrm{Pb}(\mathrm{mg} / \mathrm{kg})\end{array}$ & $\begin{array}{c}\text { Supermarket } \\
\mathrm{Pb}(\mathrm{mg} / \mathrm{kg})\end{array}$ & \\
\hline Spinach & 4 & 2,575 & 5,627 & 1,053 & 0,594 & 2,462 \\
\hline Kale & 4 & 1,515 & 6,123 & NA & 0,250 & 2,629 \\
\hline Mustard Greens & 4 & 4,145 & 1,127 & 2,061 & 4,167 & 2,875 \\
\hline \multicolumn{7}{|c|}{ Permissible Levels for Green Leafy Vegetables (mg/kg) } \\
\hline $\mathrm{WHO} / \mathrm{FAO}$ & & 0,3 & & & & \\
\hline BSN SNI 2009 & & 0,5 & & & & \\
\hline BPOM & & 0,2 & & & & \\
\hline
\end{tabular}

${ }^{*}$ NA: Not Available or Not Detected

Kale from the ' $\mathrm{B}$ ' market as the highest $\mathrm{Pb}$ sample was then given further treatment to analyze the $\mathrm{Pb}$ levels after washing and boiling process. As explained in the method, the washing and boiling process uses aqua dest to minimize the possibility of lead from the tap water. The result showed the level of $\mathrm{Pb}$ was increased in both treatments (Table 2).

Table 2. Pb Levels of Kale Wash to Boil Treatment

\begin{tabular}{lcc}
\hline \multicolumn{1}{c}{ Kale B Market } & $\begin{array}{c}\text { Initial Level of } \mathbf{~ P b} \\
(\mathbf{m g} / \mathbf{~ k g})\end{array}$ & $\begin{array}{c}\text { Pb After } \mathbf{2} \text { mins Boiled } \\
(\mathbf{m g} / \mathbf{~ k g})\end{array}$ \\
\hline Unwashed & 2,473 & 4,238 \\
Washed & 1,424 & 5,913 \\
\hline
\end{tabular}

The source of lead in these three types of vegetables can come from air, soil, or irrigation water at planting sites that have been contaminated and absorbed by plants. The process of absorption and accumulation of lead in plant bodies can occur through 3 stages. The first stage is absorption by the roots, the second from the roots to the plant parts (following the flow of transpiration) with the translocation method and the third is the localization of lead elements in cells and tissues (plant resistance systems to prevent inhibition of plant metabolism) (Priyanto \& Prayitno, 2004). Based on a similar study in Jakarta in 2014, it was found 
that there was no difference between the levels of lead elements in leaves, roots, and stems of kale vegetables (Adila \& Laz, 2016) so that this current study used estimates of the whole plant organs to be tested to the lead.

Based on the results above, vegetables from traditional markets are known to have relatively higher levels of lead compared to vegetables from supermarkets. This causes the researchers to suspect the existence of special maintenance standards on vegetables sold in supermarkets such as periodic water-spraying on the display to keep it fresh, which then wear off the remaining $\mathrm{Pb}$ attached to vegetables in supermarkets. It was reported in previous studies that $\mathrm{Pb}$ derived from pesticides sprayed on plants can also be partially reduced when plants are washed. This is because the nature of lead depends on the solubility of its compounds, where low solubility can cause more $\mathrm{Pb}$ to remain on the surface so more leaches (Onggo, 2009).

Based on the analysis of the results of the levels of lead elements in each vegetable sample, kale samples purchased at the ' $\mathrm{B}$ ' market, which is a fresh vegetable market in the city of Semarang, has the highest levels compared to other markets. The source of this vegetable comes from Bandungan District, Semarang Regency. The area, which is already well-known as a center for vegetable production, is favorable for growing vegetables due to the cold weather suits for agriculture. Fertilizers and pesticides used in agricultural activities are also a source of heavy metals in the soil. The metal content of plants is strongly influenced by the condition of metals in the soil unless there is an interaction between the metal and plants that can inhibit metal absorption (Charlena, 2004).

A study of farmers in Bandungan shows the behavior of farmers who mix 2 types of pesticides at once did not base on sufficient knowledge about the types of pesticides to be mixed (Puspitarani, 2016). The behavior of farmers who use large amounts of pesticides since Bandungan opened for an agricultural center in the 1990s is possible as one of the causes of the high content of lead in vegetables. However, further research is needed to test lead levels on the soil in Bandungan agricultural land to confirm this possibility.

To find out whether the consumption of lead concentrations exceeds the recommended limit and can endanger the community, it is necessary to look at the average intake of vegetables consumed per day by the community. The National Socio-Economic Survey Data (SUSENAS) in 2016 in table 3 below shows the amount of vegetable consumption per person per week in kilograms which then was calculated into people/day in milligrams to adjust the daily vegetable intake. WHO has recommended the daily intake of individual fruits and vegetables is 400 grams per person per day with details of 250 grams of vegetables and 150 grams of fruit (WHO, 2018). Consumption of vegetables based on these commodities shows that the daily vegetable intake of the Indonesian population is still remarkably low.

\section{Calculation of Risk Exposure}

The method of calculating exposure risk varies according to the route of the heavy metals into the human body. There are several possible routes of exposure to heavy metals to reach the human body, but in this study mainly through ingestion. To assess the health risks associated with heavy metal contamination of vegetables, daily metal intake, and risk indexes need to be calculated. Daily metal intake is calculated based on average vegetable consumption for adult male and female body weights.

The Health Risk Index (HRI) is calculated from the estimated ratio of exposure to heavy metals to test vegetables and oral reference doses. The reference oral dose (RfD) for $\mathrm{Pb}$ is $0.02 \mathrm{mg} /$ $\mathrm{kg} \mathrm{-1} \mathrm{/} \mathrm{day-1} \mathrm{(US} \mathrm{EPA,} \mathrm{2002).} \mathrm{Estimated} \mathrm{exposure}$ is obtained by dividing the daily intake of heavy metals by their safety limits. If the HRI index results show more than 1 , then it is considered unsafe for human health. Daily metal intake or the Daily Intake Metal (DIM) is determined by the following equation (Hossain, Ahmed, Abdullah, Akbor, \& Ahsan, 2015),

$$
H R I=\frac{D I M}{R f D P b}
$$

Where DIM is the daily intake of metals and RfD $\mathrm{Pb}$ is the oral dose reference for lead metal.

DIM $=$ Metal concentration $\left(\frac{\mathrm{mg}}{\mathrm{kg}}\right) \times \frac{\text { Daily Food Intake }(\mathrm{kg} / \text { day })}{\text { Body Weight }(\mathrm{kg})}$

From the calculation, assuming the average body weight of the male population is 70 $\mathrm{kg}$ and female is $60 \mathrm{~kg}$ and the average metal concentration in table 1 , we obtained the following results; 
Jurnal Riset Kesehatan, 9 (1), 2020, 69 - 71

DOI: $10.31983 /$ jrk.v9i1.5736

Table 4. Results of Calculate Health Risk Index (HRI)

\begin{tabular}{|c|c|c|c|c|c|}
\hline \multirow[b]{2}{*}{ Vegetable } & \multirow{2}{*}{$\begin{array}{c}\text { Mean } \\
\mathrm{Pb} \text { Concentration } \\
(\mathrm{mg} / \mathrm{kg})\end{array}$} & \multicolumn{4}{|c|}{ HRI } \\
\hline & & Men $\left.^{*}\right)$ & $\left.\mathrm{Men}^{* *}\right)$ & Women*) & Women $^{* *}$ ) \\
\hline Spinach & 2,462 & 0,021 & 0,440 & 0,025 & 0,513 \\
\hline Kale & 2,629 & 0,024 & 0,469 & 0,028 & 0,548 \\
\hline Mustard green & 2,875 & 0,012 & 0,513 & 0,014 & 0,599 \\
\hline Average $\mathrm{Pb}$ & 2,655 & 0,019 & 0,474 & 0,022 & 0,553 \\
\hline $\begin{array}{l}\text { Maximum } \mathrm{Pb} \\
\text { in this study }\end{array}$ & 6,123 & 0,057 & $1,093^{* * *}$ & 0,066 & $1,276^{* * *}$ \\
\hline
\end{tabular}

*) Estimated daily intake vegetables based on SUSENAS 2016 for each vegetable (refer to Table 3)

**) Estimated daily intake vegetables based on WHO Recommendation $(0,25 \mathrm{~kg} /$ person/day)

${ }^{* * *}$ ) Exceeds the health risk index $=1$

Referring to the regulations relating to Food Safety, the FAO (WHO-FAO Joint Commission on Food Additives) which issued regulations regarding the intake of heavy metals in allowed foods is $3 \mathrm{mg} /$ person/week $(0.05$ $\mathrm{mg} / \mathrm{kg}$ body weight/week), the results of this study indicate that spinach, kale and mustard greens from the market in Semarang are still within safe limits with all vegetable risk index value was $<1$. However, when referring to the daily vegetable consumption recommended by WHO which is 250 grams per person per day, then health risks will increase to close to 1.

When using the average $\mathrm{Pb}$ estimate from the results of this study $(2.655 \mathrm{mg} / \mathrm{kg})$ and daily vegetable consumption according to $\mathrm{WHO}$ standards, an unsafe weight gain (HRI =1) is 33.2 kilograms. Meanwhile, if the calculation uses the maximum concentration of $\mathrm{Pb}$ obtained from the study $(6.123 \mathrm{mg} / \mathrm{kg})$ by adjusting WHO recommendations, then it causes the risk for the community (HRI> 1). With notes, the weight referred to is for men and women 70 and 60 respectively, meaning, we need to pay attention to intake for people whose weight is less than that number. The lower the bodyweight the more the health risk increases at higher levels of lead with the same intake.

\section{Boiling Vegetables with High Pb}

The results of further tests where vegetables with the highest lead were tested, shows that the lead content decreased after the kale washed using aqua dest (Table 2). This study also examined the lead in aqua dest where the results show no lead detected. Interestingly, when the kale was boiled using aqua dest, the test results showed that the lead level was increased. This result is contrary to the results of another study in which the frequency of dyeing and the duration of boiling affect the decrease in heavy metal levels in mustard greens (Budiari,
Triani, \& Hartiati, 2016). In contrary to this study, the referred study used a stainless steel pan with boiling repetitions 3 times in 3 minutes. Meanwhile, this study uses an enamel-based pan and aluminum pan which is widely used in Indonesian households. This finding led authors to suspect the source of the lead on the boiled kale might come from the pot we used to boil.

Weidenhamer et al., (2014) in their study found that lead, aluminum, and cadmium can move from cooking utensils made from aluminum even stainless steel during cooking which then enters into food that is being cooked (Weidenhamer, Kobunski, Kuepouo, Corbin, \& Gottesfeld, 2014). Other studies on the impact of using scratched cooking utensils on heavy metal contamination of food found that the average lead content of tomatoes cooked using kitchenware with stainless steel $(26.44 \pm 0.09$ ppm), Teflon (15.48 $\pm 0,17 \mathrm{ppm})$ and aluminum $(10.0 \pm 0.07 \mathrm{ppm})$ was higher than tomatoes cooked using a fold iron skillet (Said, 2015).

The limitation of the study is the insufficient number of samples to describe the entire vegetables in the city of Semarang. Also, this study did not test the water and soil where the vegetables originated so that lead exposure is unknown in the vegetable growing environment. The source of lead exposure cannot be known from the agricultural process or at the time of distribution.

\section{Conclusion and Sugestion}

Lead levels in spinach vegetables, kale, and mustard greens originating from 3 traditional markets and 1 supermarket in Semarang exceeds the threshold agreed by $\mathrm{WHO} / \mathrm{FAO}$, SNI, and BPOM, with financial assistance on kale vegetables originating from Bandungan Sub-district agriculture, Semarang Regency. Although exceeding the specified threshold, based on the calculation of health risks 
are still in the safe category $(\mathrm{HI}<1)$ for men weighing $70 \mathrm{~kg}$ and women $60 \mathrm{~kg}$. It is suspected that there is an overuse of pesticides and other environmental contaminants on agricultural land which ultimately affect lead levels in vegetables grown in the region. Furthermore, boiling using a pan made of aluminum and enamel can also increase the lead from the cooking pan into boiled vegetables.

We suggest the Ministry of Agriculture be able to support the quality of vegetables produced by local farmers, especially those related to agricultural heavy metals residue. Regulations to control the appropriate and responsible use of pesticides and fertilizers also providing a safe end-product of vegetables from contamination for the public. While for the general community as end consumers, we suggest to wash vegetables before cooking using flowing water and consider using stainless steel or marble cooking utensils, also do not use a scratched pan to minimize exposure lead from pan to the food.

\section{Acknowledgments}

The authors thanked the University of Indonesia Public Health Faculty and Diponegoro University Environmental Engineering Laboratory.

\section{References}

Abdel-Rahman, G. N., Ahmed, M. B. M., \& Marrez, D. A. (2018). Reduction of heavy metals content in contaminated vegetables due to the post-harvest treatments. Egyptian Journal of Chemistry, 61(6), 10311037.

https://doi.org/10.21608/ejchem.2018.362 4.1303

Adila, M., \& Laz, T. (2016). Lead Levels of Kale in Three Traditional Markets in Cilandak District, South Jakarta. Al-Kauniyah Jurnal Biologi, 7(2), 99-105. https://doi.org/10.15408/kauniyah.v7i2.2 722

Agency for Toxic Substances and Disease Registry (ATSDR). (2019). Toxicological Profile for Lead. In ATSDR's Toxicological Profiles.

https://doi.org/10.1201/9781420061888_c h106

Budiari, D., Triani, I., \& Hartiati, A. (2016). Effect of Dipping Frequency and Boiling Time on Heavy Metal Content and Sensory Quality of Green Mustard (Brassica rapa I. Subsp.
Perviridis Bayley). Jurnal Rekayasa Dan Manajemen Argoindustri, 4(1).

Charlena. (2004). Lead Metal (Pb) and Cadmium

(Cd) Heavy Metal Pollution in Vegetables.

In IPB Postgraduate Doctoral Teaching Materials. Retrieved from http://www.rudyct.com/PPS702-ipb/091 45/charlena.pdf

Erdayanti, P., Hanifah, A., \& Anita, S. (2015). Analysis of Lead Metal Content in Kale and Spinach Vegetables on Jalan Kartama Pekanbaru by Atomic Absorption Spectrophotometry. JOM FMIPA Bina Widya, 2(1).

Granero, S., \& Domingo, J. L. (2002). Levels of metals in soils of Alcalá de Henares, Spain: Human health risks. Environment International, 28(3), 159-164. https://doi.org/10.1016/S0160-4120(02)00 024-7

Hermina, H., \& Prihatini, S. (2016). Overview of Vegetable and Fruit Consumption of Indonesian Population in a Balanced Nutrition Context: Further Analysis of the 2014 Individual Food Consumption Survey (SKMI). Buletin Penelitian Kesehatan, $44(3)$, 4-10. https://doi.org/10.22435/bpk.v44i3.5505. 205-218

Hossain, M. S., Ahmed, F., Abdullah, A. T. M., Akbor, M. A., \& Ahsan, M. A. (2015). Public Health Risk Assessment of Heavy Metal Uptake by Vegetables Grown at a Waste-water-Irrigated Site in Dhaka, Bangladesh. Journal of Health and Pollution, 5(9),

78-85. https://doi.org/10.5696/2156-9614-5-9.78

Kachenko, A. G., \& Singh, B. (2006). in Urban and Metal Smelter Contaminated Sites in Australia. Water, Air, and Soil Pollution, 169, 101-123.

Li, X., Hua, R., \& Yue, Y. (2004). Evaluation on contamination of $\mathrm{Cr}, \mathrm{Pb}, \mathrm{Cd}$ and $\mathrm{Cu}$ in vegetables of Hefei region. Journal of Agro-Environment Science, 31(2), 143-147.

Onggo, T. (2009). Effect of Concentration of Solutions of Various Lead Compounds ( $\mathrm{Pb}$ ) on Plant Damage, Yields and Some Criteria of Quality of Vegetables in Spinasia Leaves. Retrieved from http:// pustaka.unpad.ac.id/wp-content/ uploads/2009

Priyanto, B., \& Prayitno, J. (2004). Phytoremediation as a Special Heavy Metal pollution Recovery technology. Retrieved October 1, 2019, from 
http://ltl.bppt.tripod.com/sublab/lflora1. htm

Puspitarani, D. (2016). Description of Pesticide Use Behavior and Symptoms of Poisoning Caused by Vegetable Sprayers in Sidomukti Village, Bandungan District, Semarang Regency. Universitas Negeri Semarang.

Saha, S., Nordstrom, J., Gerdtham, U. G., Mattisson, I., Nilsson, P. M., \& Scarborough, P. (2019). Prevention of cardiovascular disease and cancer mortality by achieving healthy dietary goals for the swedish population: A macro-simulation modelling study. International Journal of Environmental Research and Public Health, 16(5). https://doi.org/10.3390/ijerph16050890

Said, S. A. (2015). The Impact of Using the Scratched Utensil on Food Contamination with Heavy Metals. IOSR Journal of Environmental Science Ver. I, 9(5), 2319-2399. https://doi.org/10.9790/2402-09517378

Sattar, M. U., Anjum, F. M., \& Sameen, A. (2015). Mitigation of heavy metals in different vegetables through biological washing techniques. International Journal of Food and Allied Sciences, 1(2), 40. https://doi.org/10.21620/ijfaas.2015240-4 4

Triani, I., Gunam, I., \& Arnata, I. (2012). Identification and Reduction of $\mathrm{Pb}$ and $\mathrm{Cd}$ Levels in Kale. In P. Sudjono, Darmanto, \& Sunjoto (Eds.), Penelitian Masalah Lingkungan di Indonesia.

UN. (2015). Food Security and Nutrition and Sustainable Agriculture. Retrieved October 15, 2019, from https://sustainabledevelopment.un.org/t opics/foodagriculture

US EPA. (2002). Region 9 preliminary remediation goals - EPA Human Health Related Guidance (No. 9355). Washington, DC.

Wani, A. L., Ara, A., \& Usmani, J. A. (2015). Lead toxicity: A review. Interdisciplinary Toxicology, 8(2), 55-64. https://doi.org/10.1515/intox-2015-0009

Weidenhamer, J., Kobunski, P., Kuepouo, G., Corbin, R., \& Gottesfeld, P. (2014). Lead exposure from aluminum cookware in Cameroon. Science of the Total Environment, 496, :339-347. https://doi.org/10.1016/j.scitotenv.2014.0 7.016

WHO. (2018). Healthy Diet. Retrieved October 9, 2019, from https://www.who.int/news-room/fact-s heets/detail/healthy-diet

Widaningrum, Miskiyah, \& Suismono. (2007). Dangers of Heavy Metal Contamination in Vegetables and Alternative Pollution Prevention. Buletin Teknologi Pascapanen Pertanian, 3, 16-27. Retrieved from ejurnal.litbang.pertanian.go.id/index.php /bpasca/article/download/5316/4510

World Health Organizations (WHO). (2003). Fruit, Vegetables and NCD Disease Prevention Facts : Global Strategy on Disease Prevention. Geneva, Switzerland.

World Health Organizations (WHO). (2018). Noncommunicable Disease. Retrieved January 14, 2020, from NCDs Factsheet website:

https://www.who.int/news-room/fact-s heets/detail/noncommunicable-diseases 